\title{
RAISING THE STANDARD OF LIVING FOR THE LOCAL COMMUNITY. CASE STUDY: TOURISM STRATEGIES IN MIHAI VITEAZU VILLAGE
}

\author{
Andreea MARIN-PANTELESCU ${ }^{* a}$, Monica Ioana TOADER ${ }^{b}$, Mihaela STTEFAN HINT ${ }^{c}$, \\ Alexandra Delia BUGNARIU ${ }^{d}$ \\ ${ }^{a}$ Bucharest University of Economic Studies, Romania, \\ b,c,d 1 Decembrie 1918 University, Alba-Iulia, Romania,
}

DOI: $10.24818 / \mathrm{IMC} / 2020 / 01.13$

\begin{abstract}
Sustainable tourism means raising the standard of living for the local community. Carrying out local tourist activities creates jobs and a constant income.

Tourism, a viable alternative, with resources raised can be represented by rural tourism. Supporting his sector by the European rural development programs, may result in additional revenue for farms located in a high potential area.

Another important point in the development of the village is increasing quality of education by promoting learning, preventing school dropout and increasing the quality of teaching.

The programs focused on Mihai Viteazu village are the sustainable development of rural space for raising the standard of living. In this way the tourism activities in the country site will be revived. Mihai Viteazu, formerly Sânmihaiu de Jos and Sânmihaiu de Sus (Hungarian: Szentmihály), is a commune in Cluj County, Transylvania, Romania, consisting of the villages of Cheia, Cornești and Mihai Viteazu (residence). The present paper is focusing on the possibilities of implementing sustainable tourism strategies in this particular Mihai Viteazu village.
\end{abstract}

KEYWORDS: investment, tourism, sustainability, local community, standard of living

\section{INTRODUCTION}

The present paper aims to carry out an analysis of the evolution of rural space in Mihai Viteazu commune under its multiple facets, with emphasis on the concepts of rural development in conditions of sustainability and multifunctionality. In this context, we mention that Romania is implementing the European model of agriculture and rural development.

Mihai Viteazu commune is part of the country of Transylvania, a region located in the south-eastern part of Cluj county, at the western limit of the Transylvanian Plain, mostly the Turda-Câmpia Turzii depression, formed in the middle and lower part of the Arieş river. Covering an area of $47.53 \mathrm{~km}^{2}$, respectively 4753 ha, of which 1129 ha (Mihai Viteazu 880 ha, Cheia 114 ha, Corneşti 135 ha). The administrative center, the village Mihai Viteazu, is on 75 national road Turda - Câmpeni, $6 \mathrm{~km}$ from Turda.

Mihai Viteazu, formerly Sânmihaiu de Jos and Sânmihaiu de Sus (Hungarian: Szentmihály), is a commune in Cluj County, Transylvania, Romania, consisting of the villages of Cheia, Cornești and Mihai Viteazu (residence).

The locality received the qualification of European village for actions of household waste collection, identification of degraded lands through illegal landfilling in the period 1998-2001, solutions for reintroducing lands in the agricultural circuit, an information campaign and attracting citizens to environmental actions surrounding.

\footnotetext{
* Corresponding author. E-mail address: marindeea@yahoo.com
} 
The analysis of the rural development strategy is a complex one (Marin-Pantelescu, 2009). Romanian rural policies and strategies must contain concrete legislative and financial elements to stimulate complex and sustainable rural development (Merce and Pocol, 2009; Otiman et al., 2013). The state, through its economy, must be removed from the naturally closed economy and introduced into the business environment (Dachin et al., 2003).

The strategy means a decision (or succession of decisions) made on the basis of a previous assessment of the current situation of an organization to meet the objectives set by the management of the organization, using the means available to the organization (Rusu et al., 2011; Rusu and Ghereş, 2008; Cucerzan, 2010). In this context, it is clear that the necessary precondition for formulating a strategy is the clear and broad understanding of the results to be achieved.

As a result of the analysis carried out on the rural development strategy of Mihai Viteazu, we intend to capitalize on the real potential, opportunities and availability for tourism development, including the creation of a stimulating and competitive business environment, meant to attract important private investments from the country and abroad.

\section{LITERATURE REVIEW}

Martinez et al. (2019) and Ristić et.al. (2019) present in their works the concept of sustainable development that represents meeting the needs of today without endangering the resources for future generations. We must not compromise the resources of future generations, says Chen et.al. (2019) in the work "The moderating role of supplier involvement in achieving sustainability".

At national level Romania has prepared strategic documents in the main fields of activity. Following these strategies, a partnership agreement was submitted to the European Union, which includes a series of challenges that require strategic investments to remove obstacles to development and unlock the country's economic potential (FAOSTAT, 2018; Agricultural Payments and Interventions Agency, n.d.). These challenges are: competitiveness, people and society, infrastructure, resources, administration and governance.

In light of these challenges and starting from the general objective established by the partnership agreement, the main thematic objectives at national level were outlined:

\section{Competitiveness}

Strengthening research, technological development and innovation

Improving access, use and quality of information and communication technologies

Increasing the competitiveness of small and medium-sized enterprises, the agricultural sector and the fisheries and aquaculture sector

\section{People and society}

Promoting sustainable and quality employment and supporting labour mobility

Promoting social inclusion, combating poverty and discrimination

Investments in education, training and professional training for acquiring skills and lifelong learning

\section{Infrastructure}

Improving access, use and quality of information and communication technologies

Promoting sustainable transport and eliminating congestion in the infrastructure of major networks.

\section{Resources}

Supporting the transition to a low carbon economy in all sectors.

Promoting adaptation to climate change, risk prevention and management.

Protecting and conserving the environment and promoting the efficient use of resources.

\section{Governance}

Strengthening the institutional capacity of public authorities and stakeholders and effective public administration.

Improving access, use and quality of information and communication technologies. 
The general long-term objective in the North-West region is "The growth of the regional economy through multidimensional and integrated development for the reduction of intra- and inter-regional disparities, respectively the increase of the regional standard of living".

The priorities of the region for the period 2014-2020 are:

Development of awareness and skills for the commune's population;

Increasing the number of jobs and incomes of the inhabitants of the region;

Increasing the accessibility of the region and the mobility of the inhabitants, goods and information;

Increasing the quality of life of the inhabitants of the region;

Increasing the efficiency and quality of the services offered by the public administration to the inhabitants of the region (Agricultural Payments and Interventions Agency, n.d.; Ferma, 2019).

Through the goals set by Mihai Viteazu Commune, through the current sustainable development strategy, it is aimed at achieving the priorities and objectives set both at national and regional (Regional context of Mihai Viteazu Commune, 2019).

\section{PRESENTATION OF MIHAI VITEAZU COMMUNE}

Mihai Viteazu commune is part of the country of Transylvania, a region located in the south-eastern part of Cluj county, at the western limit of the Transylvanian Plain, mostly the Turda-Câmpia Turzii depression, formed in the middle and lower part of the Arieş river. Covering an area of $47.53 \mathrm{~km}^{2}$, respectively 4753 ha, of which 1129 ha (Mihai Viteazu 880 ha, Cheia 114 ha, Corneşti 135 ha). The administrative center, the village Mihai Viteazu, is on 75 national road Turda - Câmpeni, $6 \mathrm{~km}$ from Turda.

When talking about the Turda area, especially the Mihai Viteazu commune, we automatically refer to the Turzii Gorge in the first place. A special tourist objective, for both Romanians and foreigners, Cheile Turzii attracts many tourists, sportsmen, scientists, young environmentalists every year.

Tthe flora and fauna of the Turda Gorge can be said to be special, the Turda Gorge representing a true monument of nature; it is a floristic reserve with unique plant specimens in Europe. Nearly 1,000 varieties of plants grown here, including rare plants.

The wild landscape in Turda Gorge convinces many tourists to come back and spend more and more time in the area. This place is also preferred by the climbers, who have the possibility to climb the stone walls of the Turda Gorge.

Due to these riches related to the flora and fauna of the Turda Gorge, this interesting place has been declared a monument of nature and protected by law.

Turda Gorge is a tourist attraction for many hikers and travelers and is one of the most popular natural monuments in Romania.

Mihai Viteazu commune is a locality with high tourist potential. Nature has provided Mihai Viteazu with many riches. Here there is an important source of water, forest and greenery, places of rest and living, conditions for tourism.

The Turda Gorge tourist objective is inscribed on the maps of international tourism. Located in an area that has picturesque hills to the northwest that are lost in the vicinity of the Apuseni mountains, Turzii Gorge covers a total of 175 ha and runs over $15 \mathrm{~km}$ in length, between Buru and Tureni. They are part of the top 5 mountaineering areas in the country, at the same time being an important place for mountain sports and recreational activities.

The two caves in Turda Gorge, which delimit the Turda Gorge on both sides, are crossed by the waters of the Hăşdate stream. They have the same height and diameter, which shows that before forming the Turda Gorge, they constituted a single cave. Their height is $3-4 \mathrm{~m}$, the length is $20-30 \mathrm{~m}$ and they branch inward. 
The high touristic potential is also offered by the numerous historical monuments that can be found in the commune's territory. Considering the list drawn up by the Ministry of Culture and National Heritage of Romania in 2010 on the territory of Mihai Viteazu commune, the following historical monuments are found: The Roman settlement from the "Descent" point dates from the Roman era, the archaeological site from the "Valea Sândului" from the. II-III AD., the Roman Catholic church in Mihai Viteazu dating from the XIX century, the Unitarian Church of Mihai Viteazu dating from the. XVIII century, the reformed-Calvinist church of Mihai Viteazu which was built between 16741684.

At the level of Mihai Viteazu Commune, according to the data of the National Institute of Statistics in 2018, the number of tourists in the tourist reception structures was 1529 persons, increasing compared to 2017, when in these structures there were 1193 persons. At the moment the economic activity in the tourism field carried out in the village of Mihai Viteazu is represented by 6 accommodation units, most of them also having public food units, of restaurant type.

Table 1. Accommodation units in Mihai Viteazu commune in 2018

\begin{tabular}{|c|c|c|c|}
\hline Name & No. of places & Stars/daisies & Location \\
\hline $\begin{array}{c}\text { Pensiunea Casa } \\
\text { Moțească }\end{array}$ & 30 & 3 daisies & Cornești \\
\hline Pensiunea Maria & 16 & 3 daisies & Mihai Viteazu \\
\hline $\begin{array}{c}\text { Hotel restaurant } \\
\text { A\&A }\end{array}$ & 20 & 2 daisies & Mihai Viteazu \\
\hline $\begin{array}{c}\text { Hotel/ restaurant } \\
\text { Ciprian }\end{array}$ & 36 & 2 stars & Cornești \\
\hline $\begin{array}{c}\text { Cabana Cheile } \\
\text { Turzii }\end{array}$ & 40 & - & Cheia \\
\hline $\begin{array}{c}\text { Summer } \\
\text { bungallows }\end{array}$ & 12 & - & \\
\hline
\end{tabular}

Source: on-site investigation

\section{IMPLEMENTATION OF THE SUSTAINABLE TOURISM DEVELOPMENT STRATEGY OF MIHAI VITEAZU COMMUNE}

We analyzed the strategy of sustainable tourism development on 5 objectives in detail:

O. 1. Development of awareness and abilities for the population of the commune

O. 2. Increasing the quality of life of the inhabitants

O. 3. Ensuring the economic sustainability of the commune

O. 4. Capitalizing on the natural and cultural heritage

O. 5. Development of basic infrastructure

Specific objective 1: "Development of awareness and skills for the commune population" It may include the following measures:

- Conducting information campaigns and raising awareness about the risks of school dropout

- Supporting specialized courses for teachers in the commune

- Facilitating transport in the urban environment for students in the high school cycle

- Development and modernization of sports infrastructure

- Modernization and endowment to urban standards of schools, kindergartens with extended program and libraries in the commune. 
The investment objective implemented the following measure: Modernization and endowment to urban standards of schools, kindergartens with extended program and libraries in the commune: Construction of kindergarten with extended program, worth 2,457,000 lei.

According to the implemented project, it includes 8 classrooms, a hall for festive activities, a gym, a dining room, a documentation and information center, offices, medical office, kitchen and several toilets.

What impresses is the space allocated to each of these rooms, a generous space that allows great freedom for children. A special thing is that the kindergarten has created jobs (financed by the local budget, the Cluj County Council and the Government of Romania).

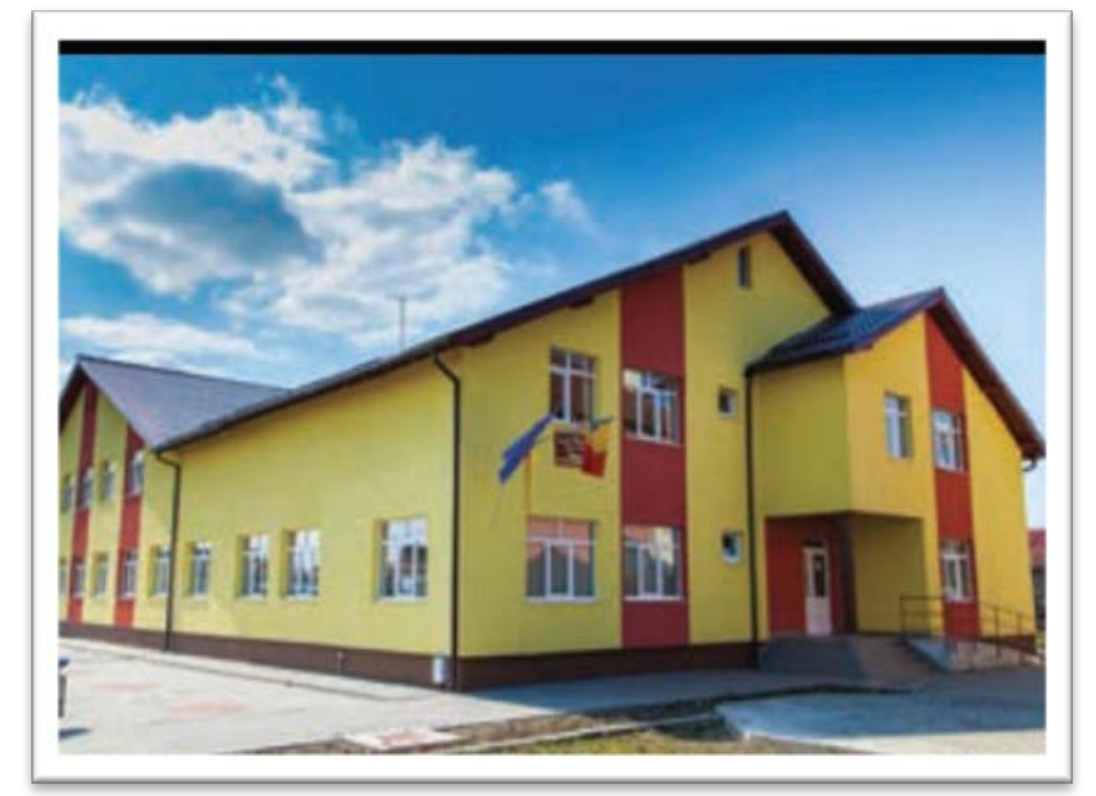

Figure 1. Modernised kindergarten of Mihai Viteazu commune

Source: photograph by the authors

The local community must be educated, in this way the tourists who come into contact with the locals will be impressed by the locals hospitality and their warm smile. Through education we offer a perspective for the tourism development in the rural area.

Specific objective 2: "Increasing the quality of life of the inhabitants"

Measures:

- Renovating, modernizing and equipping the medical offices in the municipality to standards that exceed the minimum operating limits imposed;

- Extension of the integrated system for waste collection;

- Increasing the capacity of local civil servants;

- Supporting the elderly by setting up a day center and organizing recreational activities for them.

With the help of this objective the commune Mihai Viteazu implemented the measure: Renovation, modernization and equipping the medical offices in the commune to standards that exceed the minimum operating limits imposed: Human dispensary - 700.000 lei.

The project refers to the construction of the human dispensary, in the form of a polyclinic. By implementing the project, new jobs are created for family doctors, dentists and it is possible to carry out a medical analysis collection center. In the future, the ambulance service will be implemented.

Tourists need medical care in safety and security. In this way the local dispensary can offer these medical services to both the local population and tourists. The first aid point must be present in the Mihai Viteazu commune. 


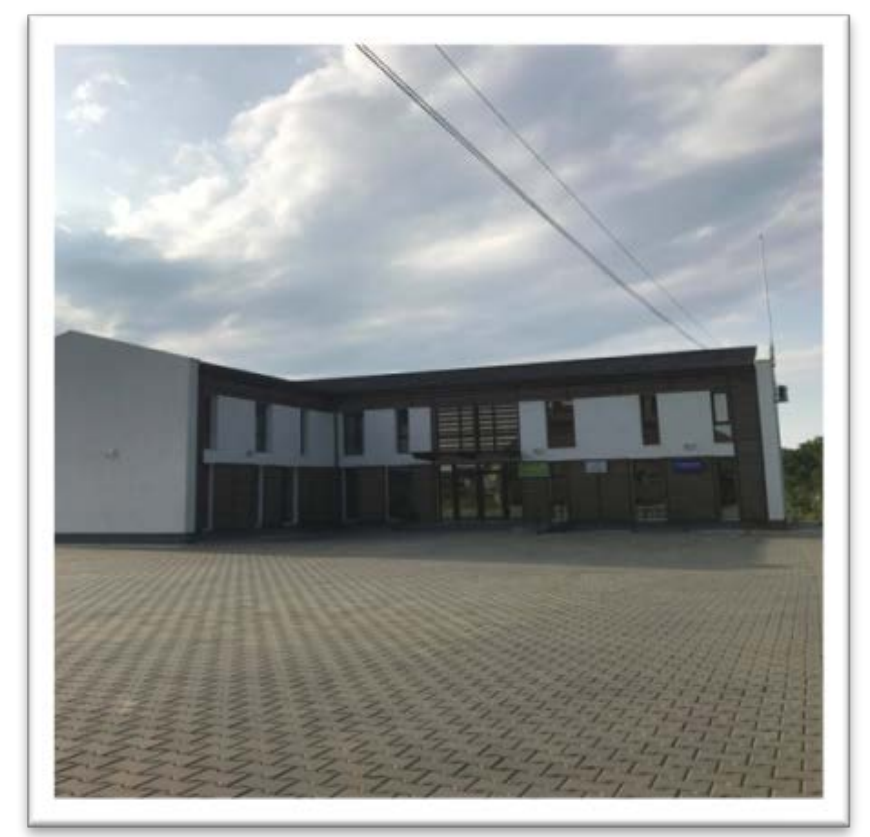

Figure 2. The human dispensary of Mihai Viteazu commune

Source: photograph by the authors

Specific objective 3: "Ensuring the economic sustainability of the commune"

The following measures:

$>$ Making investments for the development, modernization and adaptation of agricultural infrastructure;

Integration of local producers in the agri-food chain;

Support and promotion of the commune;

Planning and rehabilitation of green spaces in the locality;

Attraction of external investors in the commune.

Realization of investments for the development, modernization and adaptation of agricultural infrastructure, Project implemented: Modernization of agricultural roads, Mihai Viteazu commune, Cluj county.

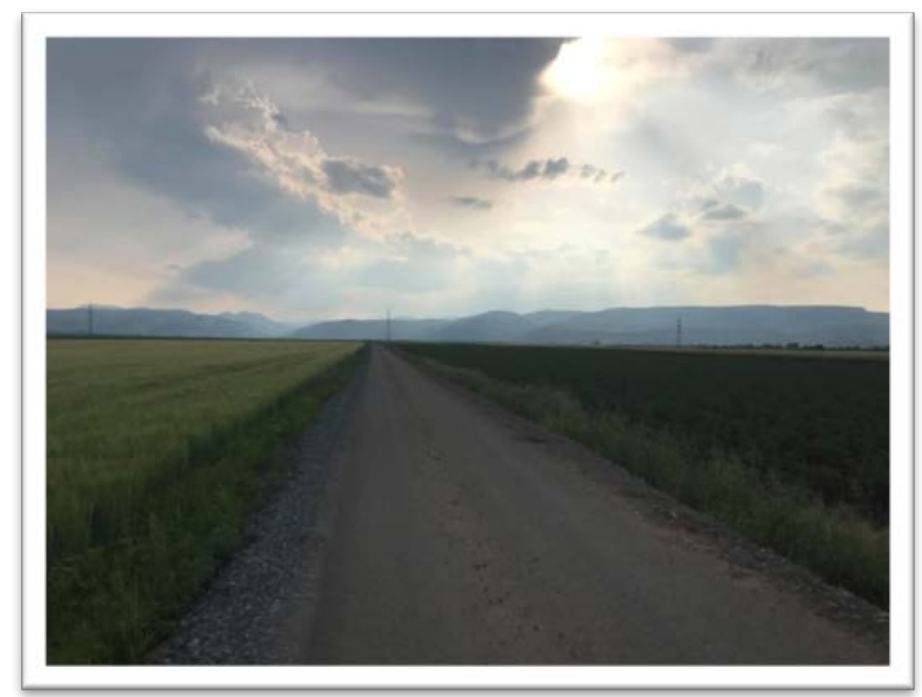

Figure 3. Sustainable agricultural road in Mihai Viteazu commune Source: photograph by the authors 
Specific objective 4: "Capitalizing on the natural and cultural heritage".

It may include the following measures:

- Revitalization of traditional local customs

- Promoting the traditional costumes and local folk dance

- Marking the holidays in the commune through artistic events

- The annual organization of Mihai Viteazu Commune Days

- Higher development and exploitation for tourist purposes of the Turda Gorge

- Implementation of a tourist circuit Mihai Viteazu - Salina Turda - Turda Gorge

- Arrangement of exhibitions or museums in order to promote local traditions.

Supporting and promoting the commune, promoting the commune (web page, brochure for presenting the commune, leaflets with the commune's opportunities), worth 9,920 lei.

The development and rehabilitation of green spaces in the commune of Mihai Viteazu, this project was carried out on an area of 1,715 square meters, the duration of implementation was 24 months, the amount being: 549.601 lei.

For ecotourism the local gastronomy offers an important attractiveness to the tourist activity. Also, the participation of tourists in agricultural activities are essential in practicing ecotourism. That is why the modernization of agricultural roads helps farmers on the one hand and tourism on the other. Specific objective 5: "Development of basic infrastructure".

The following measures:

- Rehabilitation, modernization and development of water supply infrastructure

- Rehabilitation, modernization and development of the sewerage network

- Modernization and expansion of the gas network

- Modernization and expansion of the public lighting network

- Rehabilitation and development of communal and neighbourhood roads

- Equipment for the maintenance of the commune.

Rehabilitation and development of communal roads. In the period 2014-2018, the majority of roads in Mihai Viteazu Commune were paved, the investments amounting to over 2.088.016 lei. In the period 2014-2017 in Mihai Viteazu Commune on the main street, pavements with concrete slabs were arranged on an area of 8687.35 square meters. Also, in 2014, through an investment project of 585,000 lei, pavements on the roadsides of all the three villages of 5602.70 square meters of asphalt pavement and with concrete slabs and 66 meters of concrete gutters were built.

Development of basic services: purchase of machinery, equipment and endowment for public services, of local interest, class B. Through the present project, Mihai Viteazu commune wants to endow the Emergency Situations Department, respectively the purchase of specific equipment. The necessity and the opportunity of the presence of the investment is supported by the fact that the insufficient specific equipment makes the efficiency of the interventions in emergency situations (snow, floods, fires, landslides) in the radius of Mihai Viteazu Commune to be reduced.

Thus, this project will contribute to the general objective of developing the basic services for the population in the territory of the Poarta Apusenilor LAG, with an estimated budget of 100,000 euro. Now, in 2020, we are in an exceptional and unprecedented situation, namely the Covid-19 pandemic. In these conditions, it is almost impossible to make estimates regarding the tourist activity in the rural area of Mihai Viteazu. In the last 3 months of 2020, the tourist activity was almost zero, and now, in September, the average occupancy rate is around $10 \%$, when, during this time, last year, in 2019 , the commune had a degree $80 \%$ occupancy. Tourists who opt for the Mihai Viteazu commune come with their families on a shorter vacation, looking for nature tourism in predilection. The commune, through the local authorities and the tourism operators, put in the first place the sanitary safety of the locals, of the employees and of course of the guests. This responsibility was based on the rules in force (wearing a mask indoors, installing disinfectants in public places, keeping social distance) and aims to limit the spread of the SARS-CoV-2 virus in the commune of Mihai Viteazu. 
In the short term, the general interest is to boost tourism consumption, but in the long run, tourism may become more expensive. The 2020 holidays were atypical, people turned to nature and isolated rural space. Although tourism operators have additional costs related to the implementation of health safety rules, not all of them are reflected in the price. Many have remained at the level of prices in 2019 and many tour operators are concerned to offer additional services to their guests such as dinner included in the package or free breakfast, to convince tourists to opt for Mihai Viteazu.

It is very important that the owners of tourist pensions and hoteliers communicate the safety measures they have taken and it will be important for the local authorities to help business people with investments in tourism and to promote local tourism.

And in the commune of Mihai Viteazu, the year 2020 was difficult to predict from a tourist point of view. Most boarding houses are working to prepare for 2021 and others are thinking of not opening at all in 2020. Mihai Viteazu is a tourist destination in the center of the country, so close to all, it offers an unforgettable view and opportunities to spend safe holidays, for rural tourism, active tourism, spa and gastronomic tourism and has a network of quality service providers with a lot of experience in receiving guests.

\section{CONCLUSIONS}

Mihai Viteazu commune has a sustainable tourism development strategy focused on five objectives, which we have analyzed on-site in detail. These are: developing awareness and skills for the commune population; increasing the quality of life of the inhabitants; ensuring the economic sustainability of the commune; capitalization of natural and cultural heritage and development of basic infrastructure.

Through the measures taken, the commune develops, thrives and grows, year by year. The measures are designed to be sustainable.

In the future we recommend such studies in order to analyze the possible changes that have occurred.

Establishment of a tourist information center in Mihai Viteazu commune. The local authorities ought to attract foreign investors for economic growth. Attracting new European funds by accessing specific measures for tourism and agriculture in rural areas. Greater interest from the inhabitants of this municipality to invest in the agricultural field and to set up a cooperative.

\section{REFERENCES}

Agricultural Payments and Interventions Agency (Agenția de Plăți și Intervenție pentru Agricultură - APIA). (n.d.). Programul Național de Dezvoltare Rurală 2014-2020. Retrieved on August 20, 2020, http://www.pndr.ro/pndr-2014-2020.html

Chen, L., Tang, O., \& Jia, F. (2019). The moderating role of supplier involvement in achieving sustainability. Journal of Cleaner Production, 235, 245-258.

Cucerzan M.V. (2010). Introducere în sociologie. Cluj Napoca, România: AcademicPres.

Dachin, A. et al. (2003). Evaluari ale dezvoltării durabile în România. Bucuresti, România: Editura ASE.

Marin-Pantelescu A. (2009). Diversificarea și personalizarea serviciilor turistice în contextul globalizării. Bucuresti, România: Editura ASE.

Martinez, J.M.G., Martín, J.M.M., Fernández, J.A.S., Mogorrón-Guerrero, H. (2019). An analysis of the stability of rural tourism as a desired condition for sustainable tourism, Journal of Business Research, 100, 165-174. Doi: https://doi.org/10.1016/j.jbusres.2019.03.033.

Merce E. \& C.B. Pocol (2009). Economia rurală. Cluj Napoca, România: AcademicPres. 
Otiman, P.I., Mateoc-Sîrb, N., \& Mănescu, C.M. (2013). Economie rurală. Timișoara, România: Mitron Publisher.

Ristić, D., Vukoičić, D., \& Milinčić, M. (2019). Tourism and sustainable development of rural settlements in protected areas - Example NP Kopaonik (Serbia) (2019). Land Use Policy, 89, 104231. Doi: https://dx.doi.org/10.1016/j.landusepol.2019.104231

Rusu, T., Moraru, P., \& Cacovean, H. (2011). Dezvoltare rurală. Cluj-Napoca, România: Risoprint.

Rusu, T. \& Ghereş, M. (2008). Economia mediului. Cluj-Napoca, România: Risoprint.

FAOSTAT (2018). Retrieved on August 20, 2020, from: http://www.fao.org- FAO Statistics Division, ultima accesare aprilie 2018

Ferma. (2012, January, 09). Reguli noi şi mai dure pentru tinerii fermieri. Retrieved on August 20, 2020, from: https://www.revista-ferma.ro/articole/afaceri-agricole/reguli-noi-si-mai-durepentru-tinerii-fermieri. 